\title{
Molecular screening for hemotropic mycoplasmas in captive Barbary sheep (Ammotragus lervia) in southern Brazil
}

\author{
Leonilda C. Santos ${ }^{1,2}$, Odilon Vidotto3, Vivien M. Morikawa², Nelson J. R. Santos ${ }^{3}$, Thállitha S. W. J. Vieira²,
} Ivan R. Barros Filho², Rafael F. C. Vieira² and Alexander W. Biondo²

1. Department of Sanitary Engineering, Engineering and Exact Sciences Center, Universidade Estadual do Oeste do Paraná, Foz do Iguaçu, PR 85870-650, Brazil; 2. Department of Veterinary Medicine, Universidade Federal do Paraná, Curitiba, PR 80035-050, Brazil; 3. Department of Preventive Veterinary Medicine, Universidade Estadual de Londrina, Londrina, PR 86057-970, Brazil.

Corresponding author: Rafael F. C. Vieira, e-mail: rvieira@ufpr.br

Co-authors: LCS: leonildacorreia@gmail.com, OV: vidotto@uel.br, VMM: vmmorikawa@gmail.com, NJRS: nelson.rodriguesmv@gmail.com,TSWJV: vieiratswj@gmail.com, IRBF: ivanbarf@ufpr.br, AWB: abiondo@ufpr.br Received: 10-03-2017, Accepted: 06-07-2017, Published online: 15-08-2017

doi: 10.14202/vetworld.2017.924-926 How to cite this article: Santos LC, Vidotto O, Morikawa VM, Santos NJR, Vieira TSWJ, Filho IRB, Vieira RFC, Biondo AW (2017) Molecular screening for hemotropic mycoplasmas in captive Barbary sheep (Ammotragus lervia) in southern Brazil, Veterinary World, 10(8): 924-926.

\begin{abstract}
Aim: This study is part of an active surveillance program for monitoring animal health status in endangered species, and was conducted to screen captive Barbary sheep (Ammotragus lervia) for hemoplasma infection.

Materials and Methods: A total of 12 blood samples were collected, DNA extracted and further tested by a pan-hemoplasma polymerase chain reaction protocol.

Results: Animals were clinically healthy and not infested by ectoparasites. Although housekeeping gene DNA was successfully amplified, all the Barbary sheep samples tested negative for Mycoplasma sp.

Conclusion: Notwithstanding the negative results, molecular pathogen surveys on Barbary sheep and other exotic wild mammals may provide insights regarding infection of endangered species caused by captivity stress in association with exposure to new pathogens worldwide.
\end{abstract}

Keywords: aoudads, eperythrozoonosis, hemolytic anemia, hemoplasmas.

\section{Introduction}

Hemotropic mycoplasmas (hemoplasmas) have been described as pleomorphic and uncultivable bacteria that adhere to the surface of red blood cells in several domestic and wild mammals. They may cause hemolytic anemia and/or subclinical infections [1]. Mycoplasma ovis (formerly Eperythrozoon ovis) is the main species infecting small ruminants. However, this organism has also been described in other members of the family Bovidae such as the Japanese serow (Capricornis crispus) [2], marsh deer (Blastocerus dichotomus), red brocket deer (Mazama americana), dwarf brocket deer (Mazama nana), pampas deer (Ozotoceros bezoarticus) [3,4], and reindeer (Rangifer tarandus) [5].

Infection by other hemoplasmas have also been described in wild members of the family Bovidae, including M. ovis-like in white-tailed deer (Odocoileus virginianus) [6], "Candidatus Mycoplasma erythrocervae" in marsh deer [4] and sika deer (Cervus nippon) [7,8], "Candidatus Mycoplasma haemocervae"

Copyright: Santos, et al. Open Access. This article is distributed under the terms of the Creative Commons Attribution 4.0 International License (http://creativecommons.org/licenses/by/4.0/), which permits unrestricted use, distribution, and reproduction in any medium, provided you give appropriate credit to the original author(s) and the source, provide a link to the Creative Commons license, and indicate if changes were made. The Creative Commons Public Domain Dedication waiver (http://creativecommons.org/ publicdomain/zero/1.0/) applies to the data made available in this article, unless otherwise stated. in sika deer [7,8] and Mycoplasma sp. in pampas deer [4], and white-tailed deer [9].

Barbary sheep (Ammotragus lervia) or aoudads belong to the subfamily Caprinae, sharing a series of characteristics in common with domestic mammals of the genera Capra and Ovis [10-12]. Despite being red listed as vulnerable by the International Union for Conservation of Nature [13], no hemoplasma survey has been conducted to date on this animal species.

Accordingly, the aim of this study was to screen captive Barbary sheep at Curitiba Zoo, in southern Brazil, for Mycoplasma sp. infection using a previously described pan-hemoplasma polymerase chain reaction (PCR) assay. This study is part of an active surveillance program for monitoring animal health status in endangered species.

\section{Materials and Methods}

\section{Ethical approval}

All samples were collected following ethical methods, as deliberated by the Ethics Committee on the Animal Use of UFPR with protocol number 045/2013.

\section{Sampling}

A total of 12 ethylenediaminetetraacetic acidblood samples previously surveyed for other pathogens [14] were used in this study. All the samples were stored at $-80^{\circ} \mathrm{C}$ until molecular procedures were performed. 


\section{DNA extraction and molecular processing}

DNA was extracted from $200 \mu \mathrm{L}$ of blood using a commercially available kit (Illustra Blood Genomic Prep Mini Spin Kit, GE Healthcare, Chalfont St. Giles, UK), in accordance with the manufacturer's instructions. Negative control purifications using ultrapure water were performed in parallel, to monitor cross contamination. PCR for the housekeeping gene of all mammal species, glyceraldehyde-3-phosphate dehydrogenase, was performed to ensure successful DNA extraction, as previously described [15]. Thereafter, samples were screened by means of conventional pan-hemoplasma PCR targeting the $16 \mathrm{~S}$ rDNA regions specific for hemoplasmas, using primers that had previously been described by Dieckmann et al. [16]. A M. ovis-positive goat blood sample was used as positive control. Nuclease-free water and a known uninfected goat sample were used as negative controls.

\section{Results and Discussion}

Although housekeeping gene DNA was successfully amplified, all the Barbary sheep samples tested negative for Mycoplasma sp. In this study, the animals were clinically healthy and not infested by ectoparasites, which may explain the negative results. However, we cannot rule out the possibility that these Barbary sheep may have been infected with as yet undescribed hemoplasma species that might not have been amplified by the primer set that was applied.

Among the potential causes of negative results from tests for hemoplasmas, previous reports have suggested that these include healthy animals $[17,18]$; low parasitemia [19]; sample size and type of population [17]; climatic conditions, presence of the vector and hemoplasma sequestration in tissues [20]; testing conducted during and immediately after antibiotic treatment [21]; and use of inappropriate laboratory tests [19].

To the best of authors' knowledge, this was the first study to screen Barbary sheep for hemoplasma infection. Active surveillance programs are essential for monitoring the health of endangered species.

\section{Conclusion}

Notwithstanding the negative results, molecular pathogen surveys on Barbary sheep and other exotic wild mammals may provide insights regarding infection of endangered species caused by captivity stress in association with exposure to new pathogens worldwide. Further analysis should be conducted to elucidate whether Barbary sheep could be infected by as yet undescribed hemoplasma species that cannot be amplified through the molecular assays that were applied here.

\section{Authors' Contributions}

Study design: VMM, RFCV, IRBF, and AWB. Samples collection: VMM, IRBF, and AWB.
Laboratory work: LCS, RFCV, OV, NJRS, TSWJV. Manuscript writing was done by LCS, OV, NJRS, TSWJV, VMM, RFCV, IRBF, and AWB. All authors have read and approved the final manuscript.

\section{Acknowledgments}

The authors deeply thank the Curitiba Zoo personnel. L. C. Santos was funded by the National Council for Scientific and Technological Development (Conselho Nacional de Desenvolvimento Científico e Tecnológico - CNPq) and Araucaria Foundation (Fundação Araucaria).

\section{Competing Interests}

The authors declare that they have no competing interests.

\section{References}

1. Messick, J.B. (2004) Hemotropic mycoplasmas (hemoplasmas): A review and new insights into pathogenic potential. Vet. Clin. Pathol., 33: 2-13.

2. Ohtake, Y., Nishizawa, I., Sato, M., Watanabe, Y., Nishimura, T., Matsubara, K., Nagai, K. and Harasawa, R. (2011) Mycoplasma ovis detected in free-living Japanese serous, Capricornis crispus. J. Vet. Med. Sci., 73: 371-373.

3. Grazziotin, A.L., Santos, A.P., Guimarães, A.M., Mohamed, A., Cubas, Z.S., Oliveira, M.J., dos Santos, L.C., de Moraes, W., Vieira, R.F., Donatti, L., de Barros Filho, I.R., Biondo, A.W. and Messick, J.B. (2011a) Mycoplasma ovis in captive cervids: Prevalence, molecular characterization and phylogeny. Vet. Microbiol., 152: 415-419.

4. Grazziotin, A.L., Duarte, J.M., Szabó, M.P., Santos, A.P., Guimarães, A.M., Mohamed, A., Vieira, R.F., de Barros Filho, I.R., Biondo, A.W. and Messick, J.B. (2011b) Prevalence and molecular characterization of Mycoplasma ovis in selected free-ranging Brazilian deer populations. J. Wildl. Dis., 47: 1005-1011.

5. Stoffregen, W.C., Alt, D.P., Palmer, M.V., Olsen, S.C., Waters, W.R. and Stasko, J.A. (2006) Identification of haemycoplasma species in anemic reindeer (Rangifer tarandus). J. Wildl. Dis., 42: 249-258.

6. Boes, K.M., Goncarovs, K.O., Thompson, C.A., Halik, L.A., Santos, A.P., Guimarães, A.M., Feutz, M.M., Holman, P.J., Vemulapalli, R. and Messick, J.B. (2012) Identification of a Mycoplasma ovis-like organism in a herd of farmed whitetailed deer (Odocoileus virginianus) in rural Indiana. Vet. Clin. Pathol., 419: 77-83.

7. Watanabe, Y., Fujihara, M., Obara, H., Matsubara, K., Yamauchi, K. and Harasawa, R. (2010) Novel hemoplasma species detected in free-ranging Sika deer (Cervus nippon). J. Vet. Med. Sci., 72: 1527-1530.

8. Tagawa, M., Matsumoto, K., Yokoyama, N. and Inokuma, H. (2014) Prevalence and molecular analyses os hemotrophic Mycoplasma spp. (Hemoplasmas) detected in Sika deer (Cervus nippon yesoensis) in Japan. J. Vet. Med. Sci., 76: 401-407.

9. Maggi, R.G., Chitwood, M.C., Kennedy-Stoskopf, S. and DePerno, C.S. (2013) Novel hemotropic Mycoplasma species in white-tailed deer (Odocoileus virginianus). Comp. Immunol. Microbiol. Infect. Dis., 36: 607-611.

10. Nguyen, T. and Bunch, T. (1980) Blood groups and evolutionary relationships among domestic sheep (Ovis aries), domestic goat (Capra hircus), aoudad (Ammotragus lervia) and european mouflon (Ovis musimon). Ann. Génét. Sél. Anim., 12: 169-180.

11. Cassinello, J. (1998) Ammotragus lervia: A review on systematic, biology, ecology and distribution. Ann. Zool. Fennici, 35: 149-162. 
12. González-Candela, M., León-Vizcaíno, L. and CuberoPablo, M.J. (2004) Population effects of sarcoptic mange in Barbary sheep (Ammotragus lervia) from Sierra Espunã Regional Park, Spain. J. Wildl. Dis., 40: 456-465.

13. IUCN - International Union for Conservation of Nature. The IUCN Red List of Threatened Species. Version 2015-4. Available from: http://www.iucnredlist.org. Downloaded on 27-04-2016.

14. Morikawa, V.M., Zimpel, C.K., Paploski, I.A., Lara, M.C., Villalobos, E.M., Romaldini, A.H., Okuda, L.H., Biondo, A.W. and Barros Filho, I.R. (2014) Occurrences of anti-Toxoplasma gondii and anti-Neospora caninum antibodies in Barbary sheep at Curitiba zoo, Southern Brazil. Rev. Bras. Parasitol. Vet., 23: 255-259.

15. Birkenheuer, A.J., Levy, M.G. and Breitschwerdt, E.B. (2003) Development and evaluation of a seminested PCR for detection and differentiation of Babesia gibsoni (Asian genotype) and $B$. canis DNA in canine blood samples. J. Clin. Microbiol., 41: 4172-4177.

16. Dieckmann, S.M., Winkler, M., Groebel, K., Dieckmann, M.P., Hofmann-Lehmann, R., Hoelzle, K., Wittenbrink, M.M. and Hoelzle, L.E. (2010) Haemotrophic Mycoplasma infection in horses. Vet. Microbiol., 145: 351-353.

17. Vieira, R.F., Vidotto, O., Vieira, T.S., Guimaraes, A.M., Santos, A.P., Nascimento, N.C., Santos, N.J., Martins, T.F.,
Labruna, M.B., Marcondes, M., Biondo, A.W. and Messick, J.B. (2015a) Molecular investigation of hemotropic mycoplasmas in human beings, dogs and horses in a rural settlement in southern Brazil. Rev. Inst. Med. Trop. São Paulo, 57: 353-357.

18. Vieira, T.S.W., Vidotto, O., Guimarães, A.M.S., Santos, A.P., Nascimento, N.C., Finger, M.A.P., BarrosFilho, I.R., Dornbusch, P.T., Biondo, A.W., Vieira, R.F.C. and Messick, J.B. (2015b) Use of pan-hemoplasma PCR for screening horses highly exposed to tick bites from southern Brazil. Semin. Ciênc. Agrar. 36: 291-294.

19. Vieira, R.F., Molento, M.B., Guimarães, A.M., Santos, A.P., Bonat, M., Javorouski, M.L., Popp, L., Santos, L.C., Moraes, W., Cubas, Z.S., Vieira, T.S., Vidotto, O., BarrosFilho, I.R., Biondo, A.W. and Messick, J.B. (2011) Use of a Mycoplasma suis-PCR protocol for screening a population of captive peccaries (Tayassu tajacu and Tayassu pecari). Rev. Bras. Parasitol. Vet., 20: 75-77.

20. Novacco, M., Riond, B., Meli, M.L., Grest, P. and HofmannLehmann, R. (2013) Tissue sequestration of Candidatus Mycoplasma turicensis. Vet. Microbiol., 167: 403-409.

21. Berent, L.M., Messick, J.B. and Cooper, S.K. (1998) Detection of Haemobartonella felis in cats with experimentally induced acute and chronic infections, using a polymerase chain reaction assay. Am. J. Vet. Res., 59: $1215-1220$. 